\title{
The Role of Interest Rates in the Brazilian Business Cycles*
}

\author{
Nelson F. Souza-Sobrinho ${ }^{\dagger}$
}

Contents: 1. Introduction; 2. Brazilian Business Cycles: 1994-2010; 3. Model; 4. Results; 5. Concluding Remarks; A. Appendix: Data Description.

This paper offers additional insights on the relationship between interest rates and business cycles in Brazil. First, I document that Brazilian interest rates are very volatile, counter-cyclical and positively correlated with net exports, as observed in other emerging market economies. Next, I present a dynamic stochastic general equilibrium model in which firms face working capital constraints and labor supply is independent of consumption. This parsimonious model, appropriately calibrated to the Brazilian economy, predicts that interest rate shocks can explain about one third of output fluctuations and delivers business cycle regularities consistent with the Brazilian data.

Este artigo fornece evidências adicionais sobre a relação entre taxa de juros e ciclos econômicos no Brasil. Primeiro, o artigo documenta que a taxa de juros do país é muito volátil, contracíclica e positivamente correlacionada com as exportações líquidas, conforme observado em outras economias emergentes. Em seguida, o artigo apresenta um modelo de equilíbrio geral dinâmico no qual as empresas operam com restrições de capital de giro e a oferta de trabalho é independente do consumo (ausência de efeito renda). Este modelo parcimonioso, devidamente calibrado para a economia brasileira, prevê que choques na taxa de juros são capazes de explicar cerca de um terço das flutuações do produto e gera regularidades ao longo do ciclo econômico que são consistentes com os dados do Brasil.

JEL Code: E32, F32, F41.

Keywords: Interest Rates, Business Cycles, Country Risk.

\footnotetext{
${ }^{*}$ The first version of this paper was written in 2007 during my graduate studies at the University of California Los Angeles (UCLA). I acknowledge financial support from the Brazilian Ministry of Education/CAPES. I thank Lee Ohanian, Gary Hansen, Harold Cole, Antonio Bernardo, the editor and two anonymous referees for helpful comments.

${ }^{\dagger}$ Central Bank of Brazil (Research Department) and Ibmec-DF. E-mail: nelson.souza@bcb.gov.br and nelson.sobrinho@ibmecdf.br
} 


\section{INTRODUCTION}

This paper analyzes the relationship between real interest rates and the empirical regularities of the Brazilian business cycles in recent years. A large literature has documented the business cycles properties of mature open economies and found that consumption is less volatile than output, trade balance is weakly counter-cyclical or pro-cyclical, and interest rates are pro-cyclical. ${ }^{1}$

The data for emerging market economies, however, show a different pattern:

(i) consumption is more volatile than output,

(ii) net exports are counter-cyclical and

(iii) interest rates are very volatile, counter-cyclical, positively correlated with trade balance and lead the cycle. ${ }^{2}$

Using quarterly data covering the period 1994:IV-2010:I, I also find similar empirical regularities for Brazil.

The next logical step would be to replicate such findings in a coherent quantitative model. Such an exercise is not only interesting by itself but also of central relevance for policy-makers and market participants. Because standard business cycle models of small open economies are unable to do the job, further modifications must be made in order to make sense of the empirical properties found in the data. I closely follow Neumeyer and Perri (2005), who use a similar model to study the Argentine case. The model departures from the standard business cycle literature in two important ways. First, it assumes that payments and receipts are not perfectly synchronized at the firm level, hence firms must borrow from credit markets to finance part of their working capital needs. Second, as in Greenwood et al. (1988), I assume that preferences are such that consumption and leisure are non-separable and labor supply is independent of consumption (GHH preferences).

The first assumption is equivalent to a cash-in-advance constraint but in the production side. The second assumption is now popular in small open economy models and has the purpose of making labor supply more responsive to wages. Both assumptions are crucial for generating counter-cyclical interest rates. In the model, firms must borrow to finance their working capital. Therefore, an increase in the interest rates raises the cost of working capital, reducing firms' net revenues and labor demand. The impact on equilibrium employment will depend on the nature of labor supply. GHH preferences imply that the marginal rate of substitution between consumption and leisure does not depend on consumption, which makes the labor supply a function of the real wage only. Hence, a fall in labor demand induced by higher interest rates unambiguously reduces equilibrium employment and aggregate output.

Additionally, the non-separability of GHH preferences implies that expected consumption growth depends not only on interest rates but also on future expected movements in equilibrium employment. Therefore, an interest rate shock affects consumption growth directly, as in the standard model, and also indirectly through the labor market channel. This is the key mechanism that makes consumption more responsive than output to changes in interest rates and hence more volatile than output over the business cycle.

The model in this paper departs from Neumeyer and Perri (2005) in two dimensions. First, Neumeyer and Perri assume that firms demand working capital in order to pay for the labor cost up front. In fact, they assume that firms must advance 100 percent of wages before production is sold. Here, I adopt a different route and simply assume that firms have to put aside a fraction of their production as working

\footnotetext{
${ }^{1}$ See Mendoza (1991), Backus et al. (1992), Correia et al. (1995) and Schmitt-Grohe and Uribe (2003).

${ }^{2}$ See Neumeyer and Perri (2005) and Aguiar and Gopinath (2007).
} 
capital, without having to identify how they use the working capital. This allows to calibrate the working capital parameter directly. ${ }^{3}$ Second, Neumeyer and Perri find that movements in country interest rates caused by endogenous shocks to the country risk premium are very important for explaining the Argentine's business cycles. In the Brazilian case, I find that the relevant changes in interest rates may be viewed as coming from exogenous shifts to the country risk premium, defined as the spread over the international risk-free rate. The model takes into account this important feature of the Brazilian data.

The model is calibrated to the Brazilian economy for the period 1994:IV-2010:I. When country interest rate shocks are the only source of disturbances, it can explain about a third of output fluctuations. Neumeyer and Perri also find that interest rate shocks can account for a large fraction of output fluctuations in Argentina (about 27 percent). ${ }^{4}$ Additionally, a parsimonious version of the model with country risk shocks alone is able to replicate most of the business cycle properties of the Brazilian economy in recent years.

Few papers have tried to understand the Brazilian business cycles through the lens of real business cycles (RBC) models. One exception is Kanczuk (2004), who analyzes the role of interest rates in a closedeconomy environment. Using data for the 1980s and 1990s, he concludes that interest rates shocks in Brazil are mainly determined by domestic factors such as changes in the government fiscal policy. This was probably true until mid-1990s, a period of high inflation rates, small integration with the world economy, and no regard with fiscal discipline. However, as I argue in this paper, the responsiveness of the economy to exogenous interest rate shocks caused by shifts in foreign investors' risk aversion, contagion effects and political uncertainty, has changed after mid-1990s, with the improvements in domestic fundamentals.

This paper proceeds as follows. Section 2 summarizes the empirical regularities of business cycles in Brazil. Section 3 presents the model, discusses the market equilibrium and describes its dynamics. Section 4 presents the quantitative results. Section 5 concludes.

\section{BRAZILIAN BUSINESS CYCLES: 1994-2010}

I use quarterly data from 1994:IV to 2010:I, covering all years since the launching of the Real Plan stabilization program. A detailed explanation of the dataset used in this paper can be found in Appendix A. As described in the Appendix, the empirical measure of the real interest rate I use is defined as the three-month US treasury bill rate plus the appropriate Brazilian sovereign spread, both deflated by expost inflation. The spread is the premium of dollar-denominated Brazilian bonds over US treasury bonds of comparable maturity.

The empirical regularities I find for the Brazilian data agree with most stylized facts for emerging market economies discussed in Section 1. Panel (a) of Figure 1 shows the behavior of the Brazilian interest rate, the country risk premium, and the US interest rate, over the business cycles. The country interest rate is about four times more volatile than the US rate, and its fluctuations are mainly driven by fluctuations in the country spread. Panel (b) illustrates the negative relation between interest rate and domestic output. It also highlights (by shaded areas) the four main output downturns Brazil experienced in the last fifteen years: 1995, 1998-99, 2002-03 and 2008-09.

These four recessions were preceded by increase in the interest rate, without any significant change in domestic fundamentals. In fact, the 1995 recession is associated with the Mexican crisis that contaminated most emerging markets. At that time, the Brazilian monetary authority was forced to raise the domestic interest rate in order to stabilize the currency and avoid capital outflows. A similar situation

\footnotetext{
${ }^{3}$ Even though the original model of Neymeyer and Perri also replicates the business cycle properties of the Brazilian economy, their working capital parameter, which is crucial for the results, is not directly identifiable in the data.

${ }^{4}$ In the Argentine case, Neumeyer and Perri consider interest rate shocks generated by shifts in the country risk that are related to domestic fundamentals, i.e., productivity growth.
} 
Figure 1: Real Interest Rates and Output, 1994:IV-2010:I

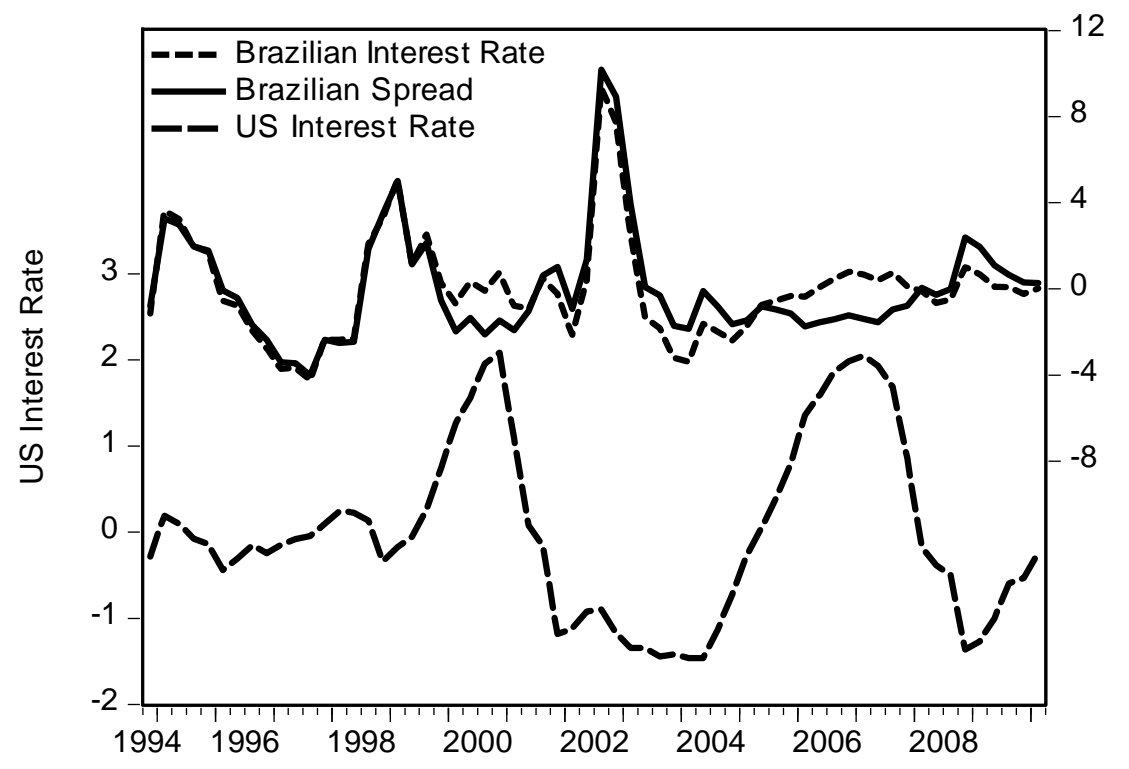

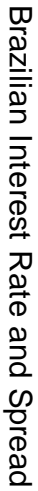

(a) Interest Rates (\% deviations from trend)

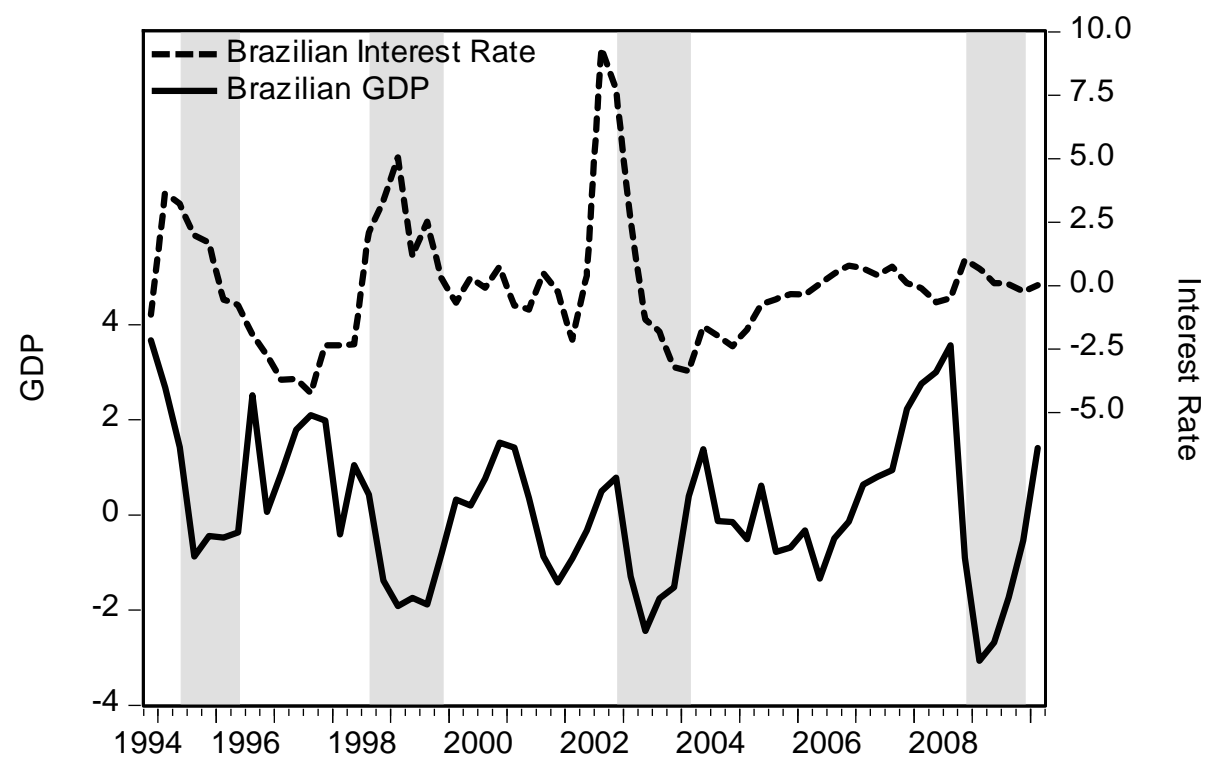

(b) Interest Rate and GDP (\% deviations from trend) 
occurred in 1998 due to the Russian crisis, which contributed to trigger the abandonment of the exchange rate peg in January 1999. The 2002-03 recession is related to the contagion from the Argentine crisis and to uncertainties surrounding the election of a left-wing president. Lastly, the 2008-09 recession was associated with the world financial crisis triggered by problems in the US sub-prime mortgage market. Despite the severity of this last crisis, the country risk premium did not increase as sharply as in the previous episodes, in part because some domestic fundamentals (e.g., large international reserves) started to play a key role as buffers against external shocks. ${ }^{5}$

Figure 2 illustrates the positive correlation between the interest rate and the trade balance, whereas Figure 3 depicts the cross-correlation between GDP and real interest rate in Brazil and in a benchmark small open developed economy (Canada). The U-shape pattern suggests that interest rates lead the cycle in Brazil, a fact that Neumeyer and Perri (2005) also observe in Argentina and in other emerging market economies. The highest correlation coefficient between the interest rate and GDP occurs for the interest rate in $t-2$ and the GDP in $t$, indicating a two-quarter phase shift in the interest rate cycle. Canada, on the other hand, exhibits a completely opposite pattern.

Figure 2: Real Interest Rate and Trade Balance, 1994:IV-2010:I

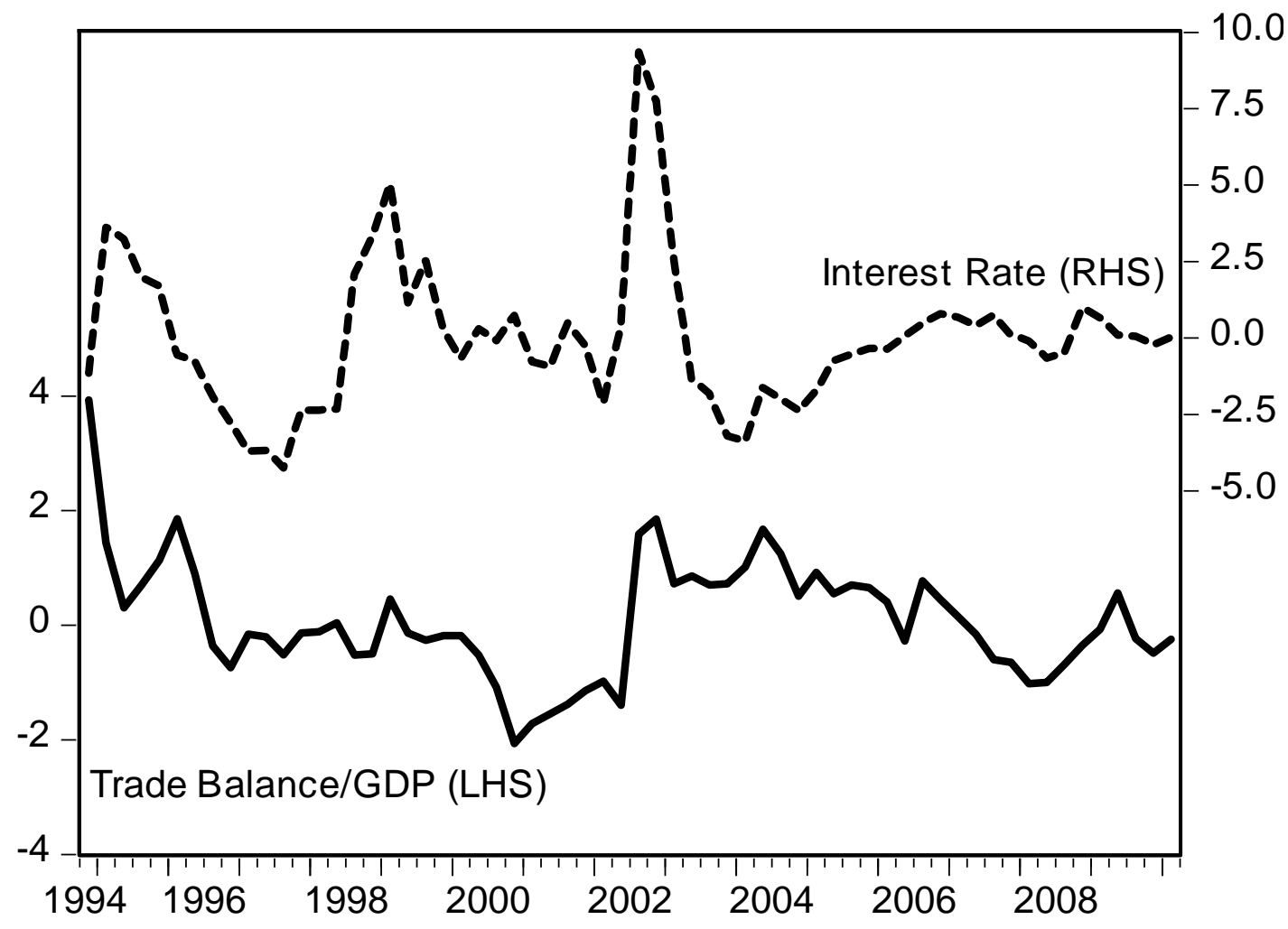

$\%$ deviations from trend

\footnotetext{
${ }^{5}$ The severity of the last recession is also associated with other transmission channels such as private agents' expectations and the collapse of world trade and trade credit.
} 
Figure 3: Correlation between $\mathrm{R}(\mathrm{t}+\mathrm{j})$ and $\mathrm{GDP}(\mathrm{t})$, Brazil \& Canada

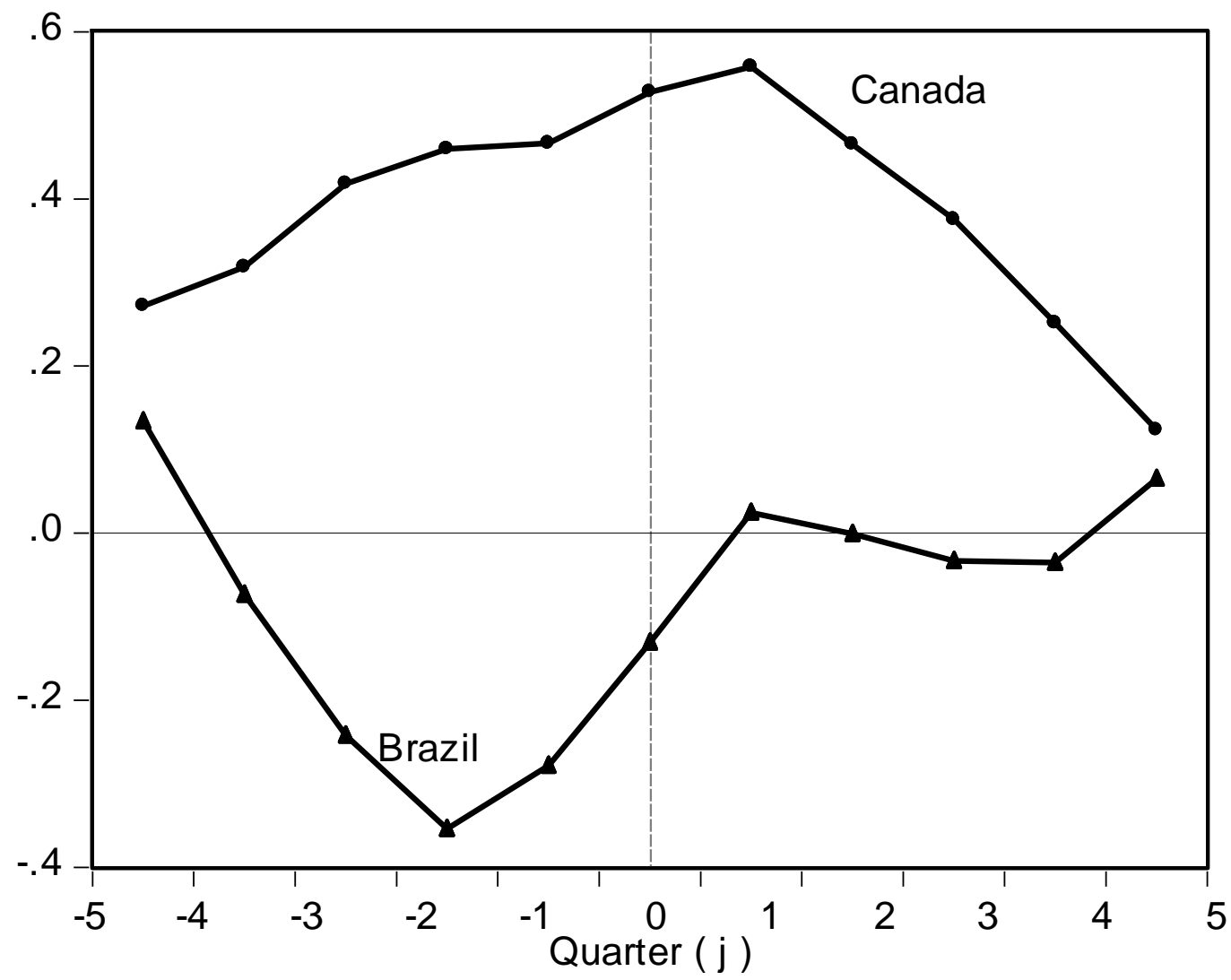

The different correlation structures may be associated with several factors. For instance, the positive correlation between interest rate and output in Canada may be a sign that the Canadian monetary authority puts a relatively large weight on output stabilization in its objective function, compared with the Brazilian case. On the other hand, the correlation structure in Brazil suggests that the monetary authority may be reacting more to deviations of realized inflation from the target than to deviations of expected inflation from the target. Such a behavior would probably imply a negative correlation between lagged real interest rate and output gap, and a very weak correlation between current real interest rate and future output gap. Alternatively, the differences may reflect the distinct nature of the shocks hitting both economies. For example, assume for a moment that both countries are strict inflation targeters and follow similar interest rate rules, but one country experiences negative supply shocks whereas the other faces positive demand shocks. Since the nature of the shocks are quite difficult to identify ex-ante, both countries would probably raise their interest rates in order to stabilize inflation. However, a negative correlation between real interest rate and output gap would more likely arise in the first country than in the second.

Table 1 compares the Brazilian business cycles with Canada's. Since there is no comparable series of hours worked I use information on employment for both countries. The Brazilian data agree with the stylized facts mentioned in Section 1: 
(i) consumption is more volatile than output, while in Canada it is less volatile;

(ii) net exports and interest rate are counter-cyclical, while in Canada they are strongly pro-cyclical; and

(iii) interest rate is very volatile compared to that of Canada.

Interestingly, the absolute values of the contemporaneous correlations between output and trade balance and between output and interest rate in Table 1 are smaller in Brazil than the average across different emerging market economies, calculated by Neumeyer and Perri (2005). This fact may be an indication that the Brazilian economy may also have many features in common with relatively mature economies, in part because of the deep structural changes it has experienced in the past two decades (e.g., trade and financial liberalization, privatization, conquest of inflation, etc). As a matter of fact, the Brazilian business cycle statistics appear to be in the middle range between those of a typical small open emerging market economy and those of a typical small open developed country.

Standard RBC models are unable to replicate the main empirical findings for the Brazilian economy. In the standard model, the relevant interest rate is the world rate, which is taken as given. Additionally, technology shocks are the main driving-force of economic fluctuations. Lastly, standard RBC models usually underestimate the relative (to output) volatility of consumption. The model I present in the next section is intended to overcome these limitations and better replicate the empirical facts. Indeed, the results presented in Section 4 suggest that the model is capable of replicating quite well the major business cycle properties of countries like Brazil.

\section{MODEL}

This section describes a model economy in which the empirical regularities discussed above can be interpreted as the equilibrium of a small open economy subject to technology shocks, international interest rates shocks and country risk shocks. Time, indexed by $t=1,2, \ldots$, is discrete and a period is a calendar quarter. Figure 4 describes the time-line of events. In the beginning of each period, all shocks are revealed and decisions take place in three markets: credit, inputs and goods markets. At the end of the same period, credit and goods markets open again and all remaining transactions are concluded. Below, I specify the behavior of firms and households along the time-line.

\subsection{Firms}

Firms operate in perfectly competitive markets and use a standard Cobb-Douglas production function to transform capital and labor into an internationally tradable commodity:

$$
Y_{t}=e^{z_{t}} K_{f t}^{\alpha} L_{f t}^{1-\alpha}, \quad 0<\alpha<1
$$

where $Y_{t}$ denotes output in period $t, K_{f t}$ is the stock of capital, $L_{f t}$ is the labor input and $z_{t}$ is a random productivity shock, which is assumed to follow a first-order Markov process. To capture the empirical evidence discussed in Section 2, I assume that firms face working capital constraints. In particular, I suppose that payments and receipts are not perfectly synchronized. In the beginning of each period, firms have to pay for labor services $\left(w_{t} L_{f t}\right)$ and capital services $\left(r_{t} K_{f t}\right)$ they rent. However, they only sell a fraction $1-\theta$ of their production. ${ }^{6}$ Hence, they must borrow $\theta Y_{t}$ from foreign lenders and/or domestic households at the interest rate $R_{t-1}$ to pay for the input services. At the end of each period,

\footnotetext{
${ }^{6}$ We can interpret the unsold production as inventories or accounts receivable maturing at the end of the period.
} 


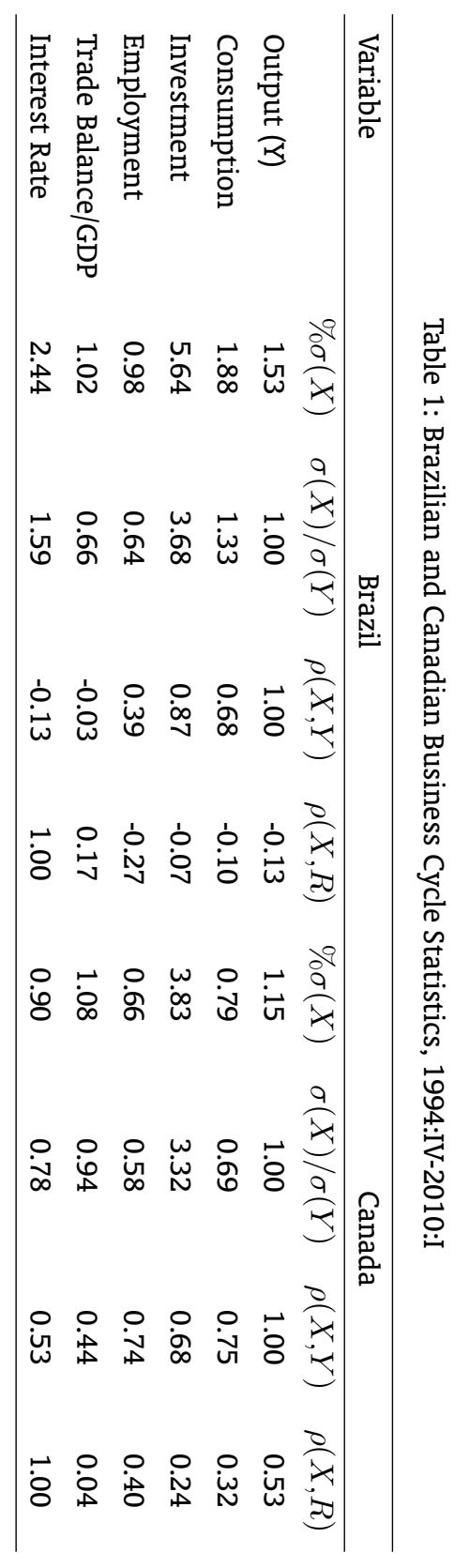




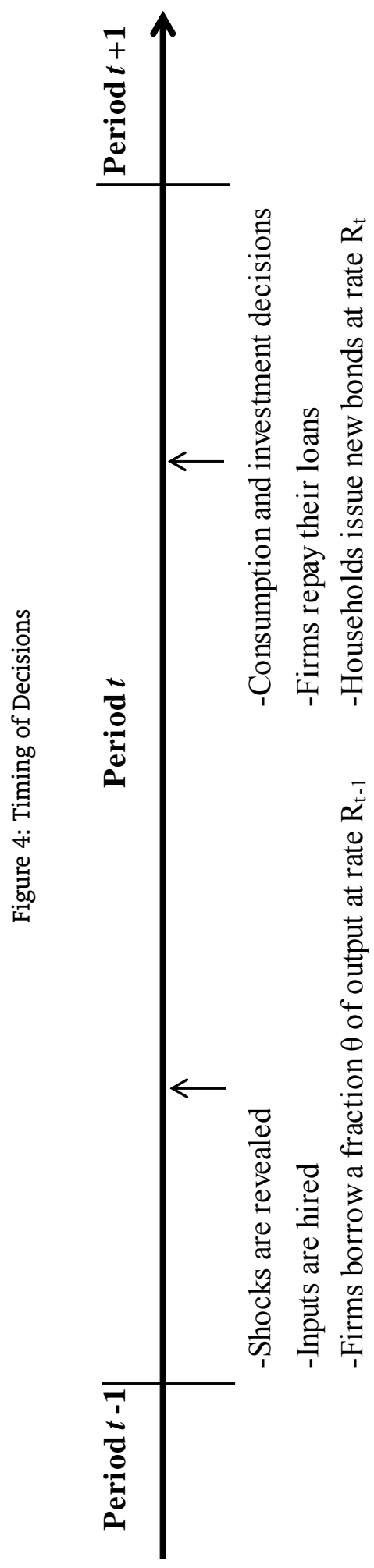


they sell the remaining output $\theta Y_{t}$ and pay $\theta Y_{t} R_{t-1}$ for the working capital they borrowed. Therefore, firm profits in period $t$ are:

$$
\pi_{f t}=\max \left\{\left[1-\theta\left(R_{t-1}-1\right)\right] Y_{t}-w_{t} L_{f t}-r_{t} K_{f t}\right\}
$$

where $\theta\left(R_{t-1}-1\right)$ is the net interest payment. Without working capital constraint, $\theta=0$, and the profit function reduces to the usual one.

\subsection{Households}

The economy is populated by a mass one of infinitely-lived households. To simplify, I abstract from population growth and technology progress and represent all variables in per capita terms. Each household has an endowment of time normalized to unity, which is allocated between leisure and market activities. The household maximizes its expected utility defined over random sequences of consumption $C_{t}$ and leisure $1-L_{t}$ :

$$
\max E_{0} \sum_{t=0}^{\infty} \beta^{t} u\left(C_{t}, 1-L_{t}\right), \quad 0<\beta<1
$$

where $u(.,$.$) is an instantaneous GHH utility function:$

$$
u\left(C_{t}, 1-L_{t}\right)=\frac{1}{1-\sigma}\left(C_{t}-\psi L_{t}^{\nu}\right)^{1-\sigma}, \quad \psi>0, \nu>1
$$

GHH preferences have been used in many small open economy models, including Mendoza (1991), Correia et al. (1995) and Neumeyer and Perri (2005). Additionally, Kanczuk (2001) concludes that GHH preferences are crucial for generating the cyclical properties consistent with the Brazilian data. Households own an initial stock of capital $K_{0}$, which they rent to firms and may augment through investment, and an initial stock of non-contingent foreign bonds $B_{0}$ that pay a stochastic gross interest rate $R_{t}$. In the beginning of each period, households rent capital and labor to firms, lend working capital, and buy a fraction $1-\theta$ of the produced output. At the end of each period, households use their proceeds to pay for consumption, investment, transaction costs and to purchase (or sell) new debt. Their period budget constraint is given by:

$$
C_{t}+I_{t}+B_{t}+\phi_{B}\left(B_{t}\right) \leq w_{t} L_{t}+r_{t} K_{t}+R_{t-1} B_{t-1}
$$

where $I_{t}$ is investment in physical capital, $B_{t}$ is the new debt purchased at $t$ and maturing next period, $B_{t-1}$ is the debt contracted in the previous period at the gross interest rate $R_{t-1}, w_{t}$ is the competitive wage rate and $r_{t}$ is the competitive rental rate of capital. The term $\phi_{B}\left(B_{t}\right)$ denotes the cost of adjusting bond holdings. Portfolio adjustment costs are commonly used in small open economy models to ensure that bond holdings are stationary ${ }^{7}$. As usual, I assume a quadratic adjustment cost for bond holdings:

$$
\phi_{B}\left(B_{t}\right)=\frac{\phi_{B}}{2} Y_{t}\left(\frac{B_{t}}{Y_{t}}-\frac{\bar{B}}{\bar{Y}}\right)^{2}, \quad \phi_{B}>0
$$

where $\frac{\bar{B}}{Y}$ is the ratio of bond holdings to GDP in steady state. The resources used for investment add to the current stock of capital and covers adjustment costs:

\footnotetext{
${ }^{7}$ Schmitt-Grohe and Uribe (2003) study three different ways to make small open economy models stationary: endogenous discount factor, debt-elastic interest rate premium and convex portfolio adjustment costs. They find that the three models deliver identical business cycle dynamics, as measured by unconditional second moments and impulse response functions.
} 


$$
I_{t}=K_{t+1}-(1-\delta) K_{t}+\phi_{K}\left(K_{t}, K_{t+1}\right)
$$

where $\delta$ is the depreciation rate and $\phi_{K}(.,$.$) is the capital adjustment cost parameter. This artifact is$ commonly used in the business cycle literature to dampen the excess volatility of investment generated by small open economy models. For simplicity, I assume that the capital adjustment cost function is also quadratic:

$$
\phi_{K}\left(K_{t}, K_{t+1}\right)=\frac{\phi_{K}}{2} \frac{\left(K_{t+1}-K_{t}\right)^{2}}{K_{t}}, \quad \phi_{K}>0
$$

Note that in steady state $\phi_{B}(\bar{B})=\phi_{K}(\bar{K}, \bar{K})=0$. Hence, the adjustment costs do not affect the long-run properties of the model.

\subsection{Shock processes}

There are three potential sources of shocks in the model: productivity shocks, world interest rate shocks and country risk shocks. The productivity shock is a standard first-order Markov process of the form:

$$
z_{t}=\rho_{z} z_{t-1}+\varepsilon_{z t}, \quad \varepsilon_{z} \sim N\left(0, \sigma_{\varepsilon_{z}}^{2}\right), \rho_{z} \in[0,1)
$$

The gross real interest rate faced by domestic households and local firms is given by:

$$
R_{t}=R_{t}^{*} D_{t}
$$

where $D_{t}$ is the spread (country risk premium) over the international risk-free interest rate $R_{t}^{*}$, which also follows a first-order autoregressive process:

$$
\hat{R}_{t}^{*}=\rho_{R^{*}} \hat{R}_{t-1}^{*}+\varepsilon_{R^{*} t}, \quad \varepsilon_{R^{*}} \sim N\left(0, \sigma_{\varepsilon_{R^{*}}}^{2}\right), \rho_{R *} \in[0,1)
$$

where the hat denotes deviation from the trend.

The country spread is a measure of the default risk on payments to international lenders. To be consistent with the evidence of Section 2, I assume that fluctuations in the country spread are mostly driven by exogenous shocks, such as shocks to foreign investors' preference for risk, contagion effects and political factors. For simplicity, I assume the following form for the exogenous country risk:

$$
\hat{D}_{t}=\rho_{D} \hat{D}_{t-1}+\varepsilon_{D t}, \quad \varepsilon_{D} \sim N\left(0, \sigma_{\varepsilon_{D}}^{2}\right), \rho_{D} \in[0,1)
$$

Regression results show that there is no significant positive correlation between the innovations to the US interest rate and those to the Brazilian country risk. In fact, in the data they display a unexpected negative but small correlation over the business cycle. Hence, I assume that $\varepsilon_{R^{*} t}$ and $\varepsilon_{D t}$ are orthogonal. Several authors, including Edwards (1984), Min (1998) and Kamin and Kleist (1999) have also found that changes in the world interest rates have no significant impact on bond spreads of developing countries, even though such evidence still is a matter of debate in the literature.

Neumeyer and Perri (2005) argue that a simple way to justify the country risk premium is to assume that residents always pay their obligations in full but there is a positive probability that the local government will confiscate part of the interest payments. Let $p_{t}$ denote the probability of confiscation and let $\tau_{t}$ be the confiscation rate, both following exogenous stochastic processes. If foreign lenders are risk-neutral, face a perfectly elastic supply of funds and always lend positive amounts to domestic 
residents, then the interest rate paid by domestic agents must satisfy $R_{t}^{*}=\left(1-p_{t}\right) R_{t}+p_{t}\left(1-\tau_{t}\right) R_{t}$, which implies that the country risk premium is given by:

$$
D_{t}=\frac{1}{1-p_{t} \tau_{t}}
$$

In this simple risk-neutral environment, exogenous changes in the probability of confiscation and in the confiscation rate are the mains sources of fluctuations in the country risk. In a more realistic setup where foreign lenders are unable to completely diversify their portfolio, or are risk averse, shifts in the perception of risk would also increase the country spread.

\subsection{Competitive equilibrium}

A competitive equilibrium for this economy is an allocation $\left\{C_{t}, L_{t}, B_{t}, K_{t+1}\right\}_{t=0}^{\infty}$ for households, an allocation $\left\{K_{f t}, L_{f t}\right\}_{t=0}^{\infty}$ for firms and a sequence of prices $\left\{w_{t}, r_{t}, R_{t}\right\}_{t=0}^{\infty}$, such that given these prices

(i) households maximize their lifetime flow of utility subject to (1) and to a non-Ponzi game condition, taking as given the initial values of capital $K_{0}$ and debt $B_{0}$,

(ii) firms maximize their profits and

(iii) all markets clear.

$$
\begin{aligned}
& \text { Goods Market : } T B_{t}=Y_{t}-C_{t}-I_{t}-\phi_{B}\left(B_{t}\right) \\
& \text { Capital Market : } K_{t}=K_{f t} \\
& \text { Labor Market : } L_{t}=L_{f t}
\end{aligned}
$$

where $T B_{t}$ is the country's trade balance. The competitive equilibrium is characterized by the following dynamic system of equations:

$$
\begin{gathered}
C_{t}+I_{t}+B_{t}+\phi_{B}\left(B_{t}\right)=\left[1-\theta\left(R_{t-1}-1\right)\right] Y_{t}+R_{t-1} B_{t-1} \\
\psi \nu L_{t}^{\nu-1}=(1-\alpha)\left[1-\theta\left(R_{t-1}-1\right)\right] \frac{Y_{t}}{L_{t}}=w_{t} \\
\lambda_{t}\left[1+\phi_{B}\left(\frac{B_{t}}{Y_{t}}-\frac{\bar{B}}{\bar{Y}}\right)\right]=E_{t} \beta \lambda_{t+1} R_{t} \\
\lambda_{t}\left[1+\phi_{K}\left(\frac{K_{t+1}}{K_{t}}-1\right)\right]=E_{t} \beta \lambda_{t+1} R_{K t+1}
\end{gathered}
$$

where $\lambda_{t}=\left(C_{t}-\psi L_{t}^{\nu}\right)^{-\sigma}$ is the lagrange multiplier on the household's budget constraint (1) and $R_{K t+1} \equiv \alpha\left[1-\theta\left(R_{t}-1\right)\right] \frac{Y_{t+1}}{K_{t+1}}+1-\delta+\frac{\phi_{K}}{2}\left[\left(\frac{K_{t+2}}{K_{t+1}}\right)^{2}-1\right]$ is the expected return on capital taking into account the adjustment cost.

Equation (6) is the economywide resource constraint. The term in brackets comes from the working capital constraint in the firms' problem. When $\theta>0$, there are less resources available for consumption and investment, hence the working capital constraint imposes a real loss on the economy. Equation (7) is the equilibrium condition in the labor market. Its left-hand side is the labor supply and its right-hand 
side is the labor demand. Note that a rise in the interest rate increases the effective labor cost and thus reduces firm's demand for labor. Since the income effect is null under GHH preferences, a reduction in the labor demand implies that both equilibrium employment and output fall unambiguously. This result is absent from standard preferences such as Cobb-Douglas in which the resulting equilibrium will depend on the size of the income and substitution effects. Finally, equations (8) and (9) are the accumulation equations for bond holdings and capital, respectively, augmented by the adjustment cost terms.

\section{RESULTS}

\subsection{Calibration}

The parameters $\nu$ and $\sigma$ are calibrated beforehand, without direct counterpart in the Brazilian data. I follow the literature and set $\nu$ to 1.5 and $\sigma$ to $2 .^{8}$ Since the choice of $\nu$ may raise controversy, I perform sensitivity analysis to assess the impact of its choice. The discount factor $\beta$ is chosen to match the average real interest rate of 2.3 per cent a quarter. The depreciation rate $\delta$ is set to 0.025 , which is a value widely used in the literature for both developed and developing countries. To calibrate the working capital parameter $\theta$, I use the following definition:

$$
\theta=\frac{\text { Working Capital }}{P Y}
$$

The empirical counterpart of $\theta$ is the amount of working capital needs relative to firm output. I use an unbalanced panel of 2158 non-financial Brazilian firms for the second half of the 1990s to calculate both variables. The amount of working capital needs is the difference between "working assets" (short-term plus medium-term assets) and "working liabilities" (short-term plus medium-term liabilities, excluding financial debt). The proxy for firm nominal output is total net revenues. The weighted (by firm assets) average of this working capital measure ranged between 0.32 and 0.39 during the sample period, with a time average of 0.35 . This figure is larger than the available estimates of working capital needs in Brazil, based on both aggregate and firm-level data. For instance, the aggregate ratio of short-term loans by commercial banks to GDP averaged 0.10 during 1996-2010. ${ }^{9}$ The problem with the aggregate proxy is that it is not stable overtime. In fact, given the Brazilian fast credit growth in recent years, the ratio doubled from 0.06 in 1996 to about 0.12 in 2010. As for the micro evidence, using similar computations and firm-level data from 1996 to 1999, Kanczuk (2004) finds a ratio of 0.11. There are two important differences between my estimates and Kanczuk's. First, Kanczuk only considers short-term assets and short-term liabilities, whereas due to data availability I had to include assets and liabilities with longer duration. Second, Kanczuk uses information only for companies listed at the Sao Paulo stock exchange (BOVESPA), which are larger and less credit-constrained than the firms in my sample. Therefore, I set $\theta=0.2$ as the benchmark value, which is in the middle range of the available estimates. I also provide sensitivity analysis to evaluate the impact of this choice on the quantitative results. ${ }^{10}$

\footnotetext{
${ }^{8}$ See Correia et al. (1995), Kanczuk (2001) and Neumeyer and Perri (2005).

${ }^{9}$ There are two credit market segments in Brazil. The first is the market of short-term (or freely allocated) loans by commercial banks to finance firm working capital and household consumption. The second is the market of long-term loans, dominated by the Brazilian Development Bank (BNDES), which is an important domestic source of funds for long-term projects.

${ }^{10}$ One might argue that even if the true working capital needs are known there still remains the question of whether shocks to interest rates are indeed transmitted to working capital finance. The evidence (not shown here) clearly suggest that the policy interest rate Selic reacts to interest rate shocks and that domestic borrowing and lending rates react to changes in the Selic rate.
} 
Table 2: Baseline Parameter Values

\begin{tabular}{lcclcc}
\hline Parameter & Symbol & Value & Parameter & Symbol & Vale \\
\hline Preferences: & & & Adj. Cost Parameter: & & \\
Discount factor & $\beta$ & 0.98 & Capital adjustment cost & $\phi_{K}$ & varies \\
Risk aversion & $\sigma$ & 2.00 & Bond adjustment cost & $\phi_{B}$ & $10^{-5}$ \\
Labor weight & $\psi$ & 2.90 & Shock Processes: & & \\
Labor exponent & $\nu$ & 1.50 & Persistence of US rate & $\rho_{R^{*}}$ & 0.93 \\
& & & Persistence of country risk & $\rho_{D}$ & 0.72 \\
Technology: & & & Persistence of productivity shock & $\rho_{z}$ & 0.95 \\
Capital share & $\alpha$ & 0.40 & Std. dev. of US rate innovation & $\sigma_{\varepsilon_{R^{*}}}$ & 0.0038 \\
Depreciation rate & $\delta$ & 0.025 & Std. dev. of country risk shock & $\sigma_{\varepsilon_{D}}$ & 0.0180 \\
Working capital requirement & $\theta$ & 0.20 & Std. dev. of technology shock & $\sigma_{\varepsilon_{z}}$ & varies \\
\hline
\end{tabular}

The parameter $\alpha$ is chosen to match the following steady state relation:

$$
\text { Capital Share }=\alpha[1-\theta(\bar{R}-1)]
$$

Since there are no reliable estimates for quarterly hours worked in Brazil over the sample period, I use micro data to calibrate $\bar{L}$. The average weekly hours per worker based on the National Household Survey (PNAD) for the years 1995-2008 was about 1/3 of the total time available, which implies a value of 2.90 for $\psi$. The steady state asset holdings of households are calibrated to match the actual net foreign debt, whose average was -65 percent of GDP during 1994-2010. The capital adjustment cost parameter $\phi_{K}$ is calibrated so that the relative simulated volatility of investment matches the actual relative volatility when either the US interest rate or the country risk premium shock or both plus the TFP shock are turned on. ${ }^{11}$ The bond holdings adjustment cost parameter $\phi_{B}$ is set to the minimum value that guarantees a stationary level of foreign debt in equilibrium.

The parameters of the shock processes are calibrated as follows. For the technology process (2), I assume that $\rho_{z}$ is equal to 0.95 , and $\sigma_{\varepsilon}$ is such that the simulated volatility of GDP matches the actual volatility when the three shocks are turned on. Since technology shocks are perceived to be quite persistent overtime, a high value of $\rho_{z}$ is typically assumed in the business cycle literature, including the seminal work of Kydland and Prescott (1982), Neumeyer and Perri (2005), and many others. The calibrated persistence makes $z_{t}$ almost indistinguishable from a unit root process, while still ensuring its stationarity. The parameters of the international interest rate (4) and the country risk (5) are obtained by simple OLS regressions. Table 2 summarizes the baseline parameter values.

\subsection{Impulse responses}

This section shows the responses of the main macroeconomic variables to shocks in aggregate productivity, US interest rate and the country risk, considering a capital adjustment cost parameter of 78 . Figure 5 shows the impulse responses to a 1 percent decrease in technology (Panel a), a 1 percentage point (p.p.) increase in the US interest rate (Panel b) and a 1p.p. increase in the country risk premium (Panel c). As expected, the reaction of the economy to a technology shock resembles the response of a standard RBC model. In particular, given the capital adjustment cost parameter, consumption and investment respond less than output and trade balance is pro-cyclical, which is at odds with the data.

\footnotetext{
${ }^{11}$ The relative volatility of investment in the model with these shocks is the average across 10000 simulations, each with 62 observations as in the data.
} 
On the other hand, shocks to the US rate and to country risk have substantially different effects through the interest rate channel. First, notice that labor and output respond with a lag because the interest rate is a pre-determined variable. On the other hand, the economy experiences an export boom on impact, as well as a relatively large drop in consumption and investment, which are larger than that of output a quarter later. Therefore, when the interest rate channel is operative the model is able to generate counter-cyclical trade balance and consumption responses that are more volatile than those of output. Notice that labor is as volatile as output in Panel b and more volatile than output in Panel c. To better understand why labor and consumption are more sensitive than output to interest rate shocks, consider the log-linearized version of (7) and (8) around their steady states (ignoring technology shocks):

$$
\begin{gathered}
\hat{l}_{t}=\frac{\alpha \hat{k}_{t}-\varphi \hat{R}_{t-1}}{1 / \epsilon_{s}-1 / \epsilon_{d}} \\
E_{t}\left(\hat{c}_{t+1}-\hat{c}_{t}\right)=E_{t}\left[\frac{1}{\sigma}\left(1-\frac{\bar{\varpi}}{\nu}\right) \hat{R}_{t}+\bar{\varpi}\left(\hat{l}_{t+1}-\hat{l}_{t}\right)\right]
\end{gathered}
$$

where $\bar{\varpi} \equiv \bar{w} \bar{L} / \bar{C}$ and $\varphi \equiv(1-\alpha) \theta \bar{R} \bar{Y} / \bar{w} \bar{L}$ are steady state constants, $\epsilon_{d}=-1 / \alpha$ is the wage elasticity of labor demand and $\epsilon_{s}=-1 /(1-\nu)$ is the wage elasticity of labor supply. Because the change in the capital stock induced by interest rate shocks is relatively small, expression (10) shows that the impact of interest rate shocks on labor mainly depends on the elasticities and on the size of the working capital constraint. Larger values of $\epsilon_{s}$ and $\theta$ imply stronger impact on employment and hence on output. The calibrated parameters of Table 4 imply that $\epsilon_{d}=-2.5, \epsilon_{s}=2$ and $\varphi=.21$. Therefore, an 1p.p. increase in the country risk reduces hours by about $0.23 \%$., and output by about $(1-\alpha) 0.23 \%$. (see Panel c).

According to (11), the increase in the interest rate has two reinforcing effects on consumption growth. One direct effect that is proportional to the intertemporal elasticity of substitution $1 / \sigma$ and one indirect effect that is proportional to employment growth, weighted by the wage bill to consumption ratio. The calibrated parameters of Table 2 imply that an 1p.p. increase in the country risk reduces consumption by $0.3 \%$. through the direct effect and by $0.7 \%$ through the indirect effect (see Panel c). Therefore, the labor market channel exacerbates the response of consumption and makes it more volatile than output.

\subsection{Business cycle statistics}

In this section, I assess the model's ability to reproduce the second moments of the actual Brazilian business cycles. Table 3 compares the simulated standard deviations with the actual ones. The simulated statistics are the averages of 10000 simulations with 62 periods each, the same length of the data sample. I consider 6 different models: model 1 (only US rate shocks), model 2 (US rate and TFP shocks), model 3 (country risk shocks), model 4 (country risk and TFP shocks), model 5 (US rate and country risk shocks), and model 6 (all three shocks). As in Neumeyer and Perri (2005), I generate the innovations to the world interest rate and to the country risk premium using equations (4) and (5) and the actual HP-filtered data so that these series in the model mimic their counterpart in the data. Productivity shocks are randomly generated by equation (2), and their standard deviation are set so that the standard deviation of output in the models 2,4 and 6 exactly matches the actual volatility of GDP.

The model with only US rate shocks (model 1 ) is able to generate 28 percent of the actual volatility of GDP and only 42 percent of the interest rate volatility. The model overestimates the volatilities of labor and of aggregate demand components. Once I turn on the TFP shocks (model 2), the relative volatilities become more aligned with those in the data, especially the volatility of labor. The model with only country risk shock (model 3) explains a third of the actual volatility of GDP, and when augmented by TFP shocks (model 4), it does a better job of explaining the relative volatilities, even tough it still overestimates that of trade balance. Notice that by construction models 3 and 4 slightly overestimate 
Figure 5: Impulse Responses
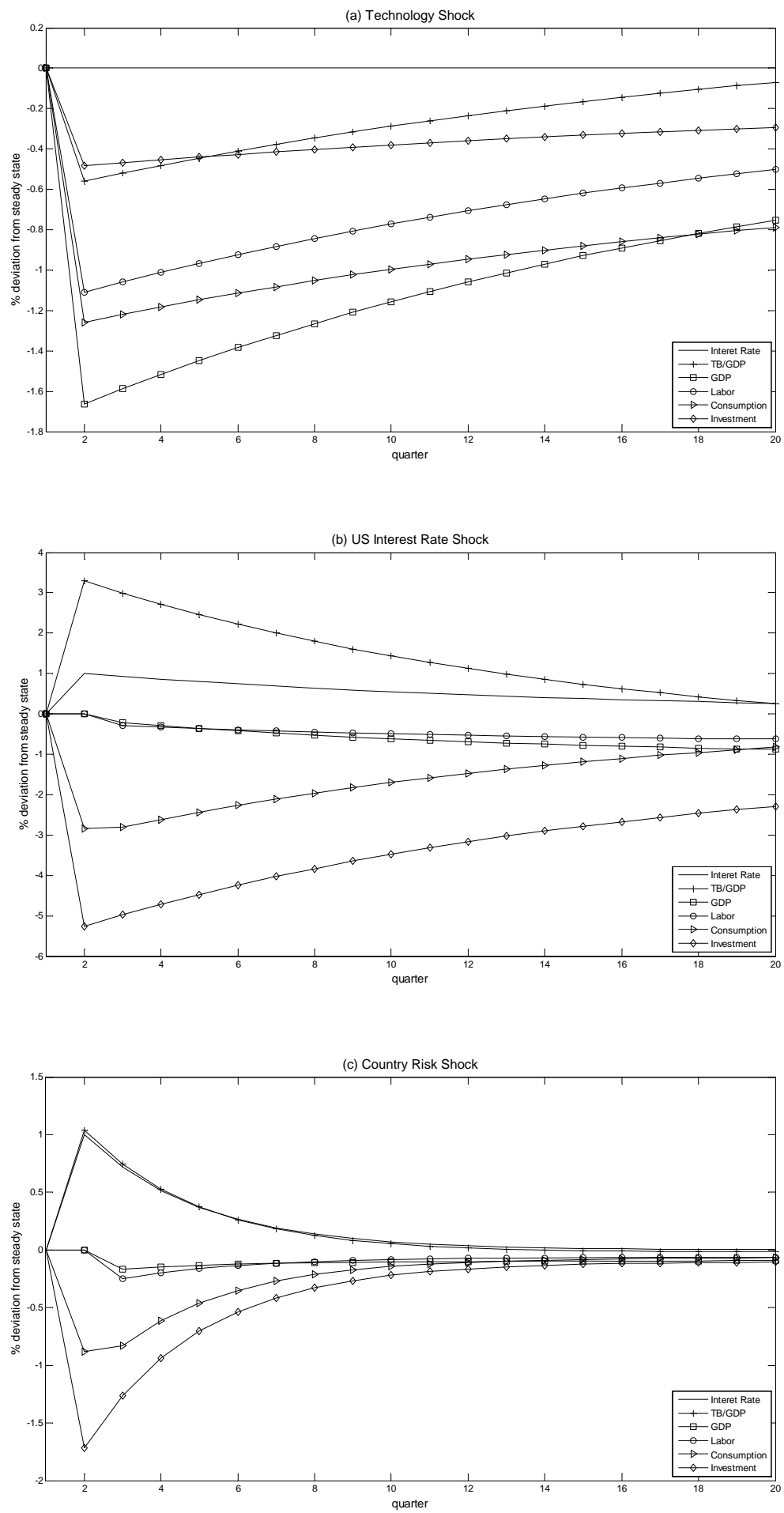
Table 3: Actual and Simulated Volatilities

\begin{tabular}{lcccccc}
\hline Data and Models & \multicolumn{5}{c}{$\sigma(X) / \sigma(G D P)$} \\
\hline & $\sigma(G D P)$ & $\sigma(R)$ & $\mathrm{C}$ & Inv & Labor & TB/GDP \\
Brazilian Data & 1.53 & 2.44 & 1.33 & 3.68 & 0.64 & 0.66 \\
& & & & & & \\
No Country Risk & & & & & & \\
$\quad$ 1. US rate shocks & 0.44 & 1.03 & 7.01 & 12.86 & 0.86 & 7.93 \\
$\quad$ 2. US rate and TFP shocks & 1.53 & 1.03 & 2.16 & 3.68 & 0.68 & 2.30 \\
Country Risk & & & & & & \\
$\quad$ 3. Country risk shocks & 0.49 & 2.59 & 5.33 & 11.64 & 1.33 & 6.08 \\
$\quad$ 4. Country risk and TFP shocks & 1.53 & 2.59 & 1.84 & 3.68 & 0.76 & 1.93 \\
Country Risk and US Rate & & & & & & \\
$\quad$ 5. Country risk and US rate shocks & 0.51 & 2.44 & 6.13 & 10.84 & 1.25 & 6.78 \\
$\quad$ 6. Country risk, US rate and TFP shocks & 1.53 & 2.44 & 2.22 & 3.68 & 0.76 & 2.31 \\
\hline
\end{tabular}

Table 4: Correlations with GDP

\begin{tabular}{|c|c|c|c|c|c|}
\hline & $\mathrm{R}$ & C & Inv & Labor & TB/GDP \\
\hline Brazilian Data & -0.13 & 0.68 & 0.87 & 0.39 & -0.03 \\
\hline \multicolumn{6}{|l|}{ No Country Risk } \\
\hline 1. US rate shocks & -0.20 & 0.23 & 0.27 & 0.94 & -0.13 \\
\hline 2. US rate and TFP shocks & -0.06 & 0.38 & 0.15 & 0.99 & 0.08 \\
\hline \multicolumn{6}{|l|}{ Country Risk } \\
\hline 3. Country risk shocks & -0.44 & 0.57 & 0.47 & 0.95 & -0.42 \\
\hline 4. Country risk and TFP shocks & -0.14 & 0.54 & 0.24 & 0.95 & 0.00 \\
\hline \multicolumn{6}{|l|}{ Country Risk and US Rate } \\
\hline 5. Country risk and US rate shocks & -0.48 & 0.31 & 0.27 & 0.96 & -0.16 \\
\hline 6. Country risk, US rate and TFP shocks & -0.17 & 0.41 & 0.17 & 0.96 & 0.06 \\
\hline
\end{tabular}

the volatility of the interest rate because it ignores the small negative covariance between US rate shocks and country risk shocks. When both US rate and country risk shocks are turned on (model 5), the model still explains a third of the output volatility, as in the country risk shock model (model 3). This result suggests that innovations to the country risk premium are more important to explain business cycle volatility than shocks to the world interest rate. Finally, the last line of Table 3 suggests that the model considering all shocks (model 6) still overestimates the relative volatilities of consumption and trade balance.

Table 4 presents the cross-correlations with output for the six models. Although the signs of the correlation in most models are about right, the models tend to overestimate the correlations of output with interest rate and with labor, and underestimate the correlations of output with consumption and with investment. Notice that TFP shocks tend to reverse the sign of the correlations between output and trade balance, even though their magnitudes are small. In fact, Figure 5 showed that TFP shocks tend to generate pro-cyclical trade balance thus dampening the countercyclical behavior produced by interest rate shocks. 
Table 5: Correlations with R

\begin{tabular}{lccccc}
\hline & Y & C & Inv & Labor & TB/GDP \\
\hline Brazilian Data & -0.13 & -0.10 & -0.08 & -0.27 & 0.17 \\
No Country Risk & & & & & \\
$\quad$ 1. US rate shocks & -0.20 & -1.00 & -1.00 & -0.50 & 1.00 \\
$\quad \begin{array}{l}\text { 2. US rate and TFP shocks } \\
\text { Country Risk }\end{array}$ & -0.06 & -0.93 & -0.99 & -0.18 & 0.99 \\
$\quad$ 3. Country risk shocks & -0.44 & -0.99 & -1.00 & -0.61 & 1.00 \\
$\quad \begin{array}{l}\text { 4. Country risk and TFP shocks } \\
\text { Country Risk and US Rate }\end{array}$ & -0.14 & -0.89 & -0.99 & -0.34 & 0.99 \\
$\quad \begin{array}{l}\text { 5. Country risk and US rate shocks } \\
\text { 6. Country risk, US rate and TFP shocks }\end{array}$ & -0.48 & -0.78 & -0.77 & -0.61 & 0.73 \\
\hline
\end{tabular}

The model statistics are averages of 10000 simulations with 62 periods each.

The capital adjustment cost parameter is set to 74 (models 1, 2), 60 (models 3, 4) and 78 (models 5, 6).

Table 5 reports the cross-correlations with the country interest rate. All models generate correlations with the expected sign but they tend to overestimate their absolute values. Figure 6 complements the information of Tables 4 and 5. It depicts the cross-correlations between output and interest rate for 5 lags and leads in the model that combines TFP shocks and country risk shocks (model 4) and the model with all shocks (model 6). Notice that in the data the interest rate leads the cycle by two quarters, whereas in the models it leads the cycle by one quarter because by construction interest rate shocks take only one quarter to affect output in the model.

To conclude this section, it is fair to say that the simple modified RBC model developed in this paper, especially its version with country risk shocks, is able to replicate quite well the main business cycles properties of the Brazilian economy. As a matter of fact, the correlation between the actual and simulated GDP is the highest in the model with only country risk shocks (model 3), reaching 0.40 . Figure 7 plots the actual GDP and the simulated GDP using model 3. The simulated series depicts cyclical fluctuations that are qualitatively similar to those of the actual series. As expected, the simulated GDP displays smaller deviations from trend than the actual one, especially in the last recession. As I mentioned in Section 1, this last output downturn was reinforced by other transmission channels which are ignored in the model.

Overall, the model generates volatile and counter-cyclical interest rates, consumption more volatile than output, counter-cyclical trade balance, the right sign for the cross-correlations of output and of interest rates with key macroeconomic indicators, and the right correlation structure between interest rate and GDP. These results are very encouraging compared to the counterfactual predictions of a standard RBC model.

\subsection{Sensitivity analysis}

Two crucial parameters for the previous results are the wage elasticity of labor supply $\epsilon_{s}=-1 /(1-$ $\nu$ ) and the working capital requirement $\theta$. In this section, I perform sensitivity analysis to assess the quantitative implications of these parameter choices. Table 6 reports two key statistics - the volatility of output in the model relative to the actual volatility, and the correlation between the interest rate and output - for several parameter values. To perform this exercise, I use the parsimonious model with only country risk shocks (model 3).

The first experiment considers a low labor exponent $(\nu=1.1)$, which implies a labor supply elasticity of 10 . The second experiment is the baseline model, with a labor supply elasticity of 2 . The last exercise considers $(\nu=3)$, which implies a labor supply elasticity of only 0.5 . For a given working 
Figure 6: Correlation between $\mathrm{R}(\mathrm{t}+\mathrm{j})$ and $\mathrm{GDP}(\mathrm{t})$

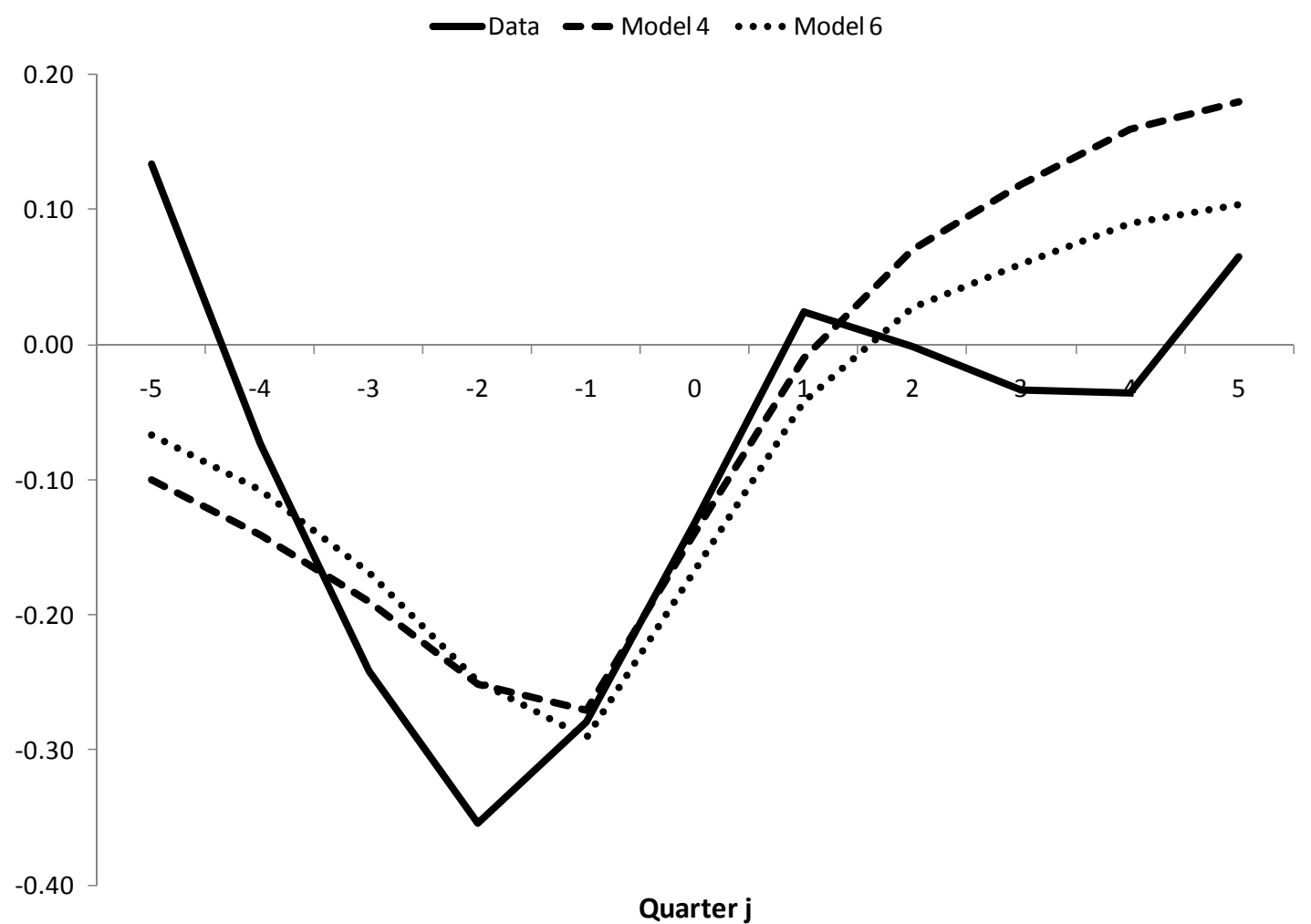

capital parameter, as the labor exponent increases (or as the labor supply elasticity decreases), the response of labor to interest rate shocks decreases, and so does the predicted volatility of output and the absolute value of the correlation between output and interest rate (see equation (10) again). On the other hand, for a given labor supply elasticity, the higher the working capital requirement the higher is the explained volatility of output and the larger is the correlation between output and interest rate. Note that when $\theta=0$, model 3 collapses to the standard RBC model, which has little hope of explaining the Brazilian Data. However, if we consider a low but positive value for the working capital parameter such as the one calibrated by Kanczuk (2004), the model with baseline elasticity is still able to explain about a quarter of the GDP volatility. Finally, the model with the two baseline parameter values not only delivers counter-cyclical interest rates but also explains about a third of the output fluctuations, as mentioned before.

The previous experiments provide two important insights regarding the interaction between labor supply elasticity and working capital constraint. First, the model requires relatively high labor supply elasticity and positive working capital requirement in order to be consistent with the data. Second, as long as firms face some working capital constraint, model 3 still successfully explains a large fraction of output fluctuations. 
Figure 7: Actual GDP and GDP Simulated by Model 3 (\% deviation from trend)

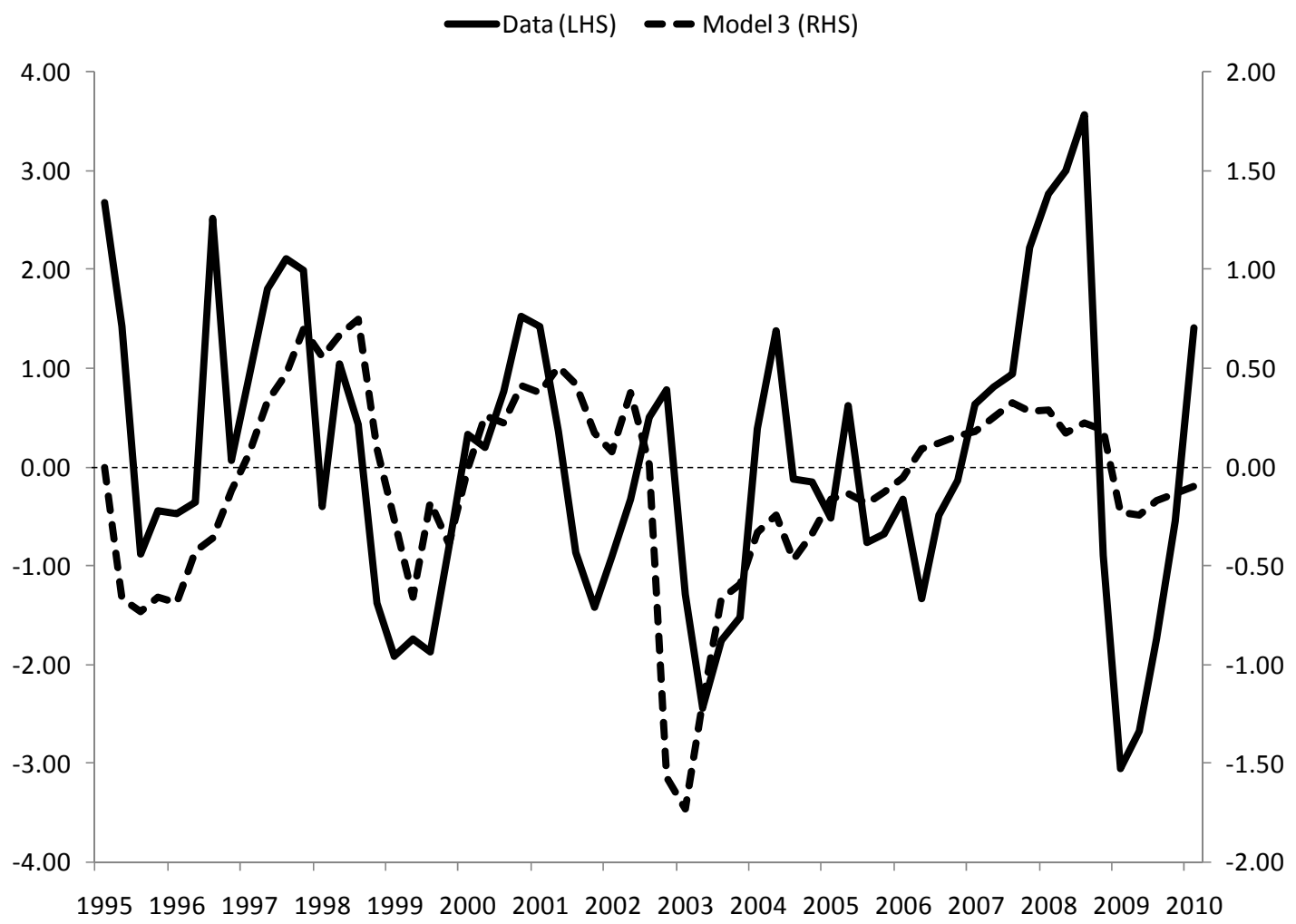

Table 6: Sensitivity Analysis for the Country Risk Model (Model 3)

\begin{tabular}{lcccccc}
\hline \multirow{2}{*}{ Working Capital } & \multicolumn{7}{c}{$\nu=1.1$} & \multicolumn{2}{c}{ Preferences } \\
& $\begin{array}{l}\sigma_{Y_{\text {model }}} \\
\sigma_{Y_{\text {data }}}\end{array}$ & $\rho(Y, R)$ & $\frac{\sigma_{Y_{\text {model }}}}{\sigma_{Y_{\text {data }}}}$ & $\rho(Y, R)$ & $\frac{\sigma_{Y_{\text {model }}}}{\sigma_{Y_{\text {data }}}}$ & $\rho(Y, R)$ \\
\hline$\theta=0$ & 0.24 & 0.16 & 0.18 & 0.15 & 0.13 & 0.14 \\
$\theta=0.11$ (Kanczuk, 2004) & 0.36 & -0.35 & 0.24 & -0.27 & 0.15 & -0.10 \\
$\theta=0.20$ (baseline) & 0.52 & -0.50 & 0.32 & -0.44 & 0.17 & -0.25 \\
$\theta=0.35$ (firm panel data) & 0.81 & -0.60 & 0.47 & -0.56 & 0.22 & -0.40 \\
$\theta=1.00$ & 2.11 & -0.68 & 1.20 & -0.67 & 0.48 & -0.61 \\
\hline
\end{tabular}

The capital adjustment cost parameter is set to 60 in all experiments. 


\section{CONCLUDING REMARKS}

Fluctuations in the interest rates driven by changes in the country risk premium played an important role in the Brazilian business cycles in the last fifteen years. Interest rate spikes were associated with output downturns and export booms. The main goal of this paper was to find out how much of the output volatility in Brazil can be explained by interest rates fluctuations alone. To achieve this goal, I followed Neumeyer and Perri (2005) and developed a model with equilibrium prices and allocations that allows interest rates to have an effect on business cycles. In this model, the interest rate is determined by the international interest rate plus a country risk premium. The model is calibrated such that the relevant parameter values match key empirical moments of the Brazilian economy.

The numerical experiments suggest that we can interpret the Brazilian business cycle properties in recent years as the equilibrium of a model in which payments and receipts of firms are not synchronized and in which labor supply is not significantly affected by income. Given the calibrated parameters, fluctuations in the country risk are able to account for a third of output fluctuations.

The main results suggest that developing countries should design and implement reforms that reduce their default risk and hence their inherent volatility. In fact, the combination of fiscal discipline, inflation under control, floating exchange rate regimes and accumulation of international reserves, both in Brazil and in other emerging market economies, have helped to achieve stable and historically low country risk premia in recent years. The low response of the Brazilian risk premium during the 2008-09 world financial crisis corroborates the increasing importance of those fundamentals. Further improvements in domestic fundamentals, together with a favorable external position, are likely to dampen even more the negative effects of external shocks on emerging market economies.

The simple model developed in this paper ignores potentially important economic fundamentals and transmission channels, especially the exchange rate. We observe in the data that shocks to the country risk premium are associated with depreciation of the real exchange rate, as predicted by standard uncovered interest rate parity conditions. In turn, exchange rate depreciations tend to lower investment spending because domestic firms depend on the imports of machinery, equipment and technology from abroad. Including the exchange rate and other relevant transmission mechanisms in the model is left for future research.

\section{BIBLIOGRAPHY}

Aguiar, M. \& Gopinath, G. (2007). Emerging market business cycles: The cycle is the trend. Journal of Political Economy, 115(1):69-102.

Backus, D., Kehoe, P., \& Kydland, F. (1992). International real business cycles. The Journal of Political Economy, 100(4):745-775.

Correia, I., J.Neves, \& Rebelo, S. (1995). Business cycle in a small open economy. European Economic Review, 39(6):1089-1113.

Edwards, S. (1984). Ldc foreign borrowing and default risk: An empirical investigation, 1976-80. The American Economic Review, 74(4):726-734.

Greenwood, J., Hercowitz, Z., \& Huffman, G. (1988). Investment, capacity utilization and the real business cycle. The American Economic Review, 78(3):402-417.

Kamin, S. \& Kleist, K. V. (1999). The evolution and determinants of emerging market credit spreads in the 1990s. BIS Working Paper, 68.

Kanczuk, F. (2001). Business cycle in a small open Brazilian economy. Economia Aplicada, 5(3):455-471. 
Kanczuk, F. (2004). Real interest rates and Brazilian business cycles. Review of Economics Dynamics, $7(2): 436-455$.

Kydland, F. E. \& Prescott, E. C. (1982). Time to build and aggregate fluctuations. Econometrica, 50(6):1345-1370.

Mendoza, E. (1991). Real business cycles in a small open economy. The American Economic Review, 81(4):797-818.

Min, H. (1998). Determinants of emerging market bond spreads: Do economic fundamentals matter? The World Bank Working Paper, 1899.

Neumeyer, P. \& Perri, F. (2005). Business cycles in emerging economies: The role of interest rates. Journal of Monetary Economics, 52(2):345-380.

Schmitt-Grohe, S. \& Uribe, M. (2003). Closing small open economy models. Journal of International Economics, 61(1):163-185.

\section{A. APPENDIX: DATA DESCRIPTION}

This Appendix describes in detail the data used in Section 1 and in the calibration.

\section{A.1. Brazilian data:}

- GDP, Consumption, and Investment: quarterly real indexes, seasonally adjusted, from the Brazilian Institute of Geography and Statistics (IBGE).

- Trade Balance/GDP: ratio of nominal net exports to nominal GDP, from the quarterly National Accounts of IBGE.

- Country Risk: measured by the EMBI Brazil calculated by JP Morgan, and deflated by ex-post GDP deflator inflation.

- Interest Rate: US rate times the country risk, according to equation (3). The US rate is measured by the nominal interest rate on the 3-month treasury bills, from the Fed Saint Louis (Fred@Database), deflated by ex-post inflation. The latter is the average of the GDP deflator inflation in the current period and in the three preceding periods. The GDP deflator is taken from the Bureau of Economic Analysis (BEA).

- Labor: quarterly average of the index of employed people in the major metropolitan areas, from the Monthly Employment Survey (PME) of IBGE.

- Short-term Loans: freely allocated loans of the banking system to non-financial firms, contracted at market interest rates, from Central Bank of Brazil.

\section{A.2. Canadian data:}

- National Accounts: quarterly series in current and base-year Canadian Dollars, from OECD. Trade balance-to-GDP ratio is constructed as explained above.

- Interest Rate: nominal interest rate on the 3-month Canadian Treasury Bills, from Bank of Canada, deflated by the Canadian GDP deflator inflation.

- Labor: quarterly average of the employment index, from OECD. 